\title{
A Histopathological Study of Endometrium in Infertility
}

\author{
Dr. Silbina Murmu ${ }^{1}$,Dr. Budhan Baitha ${ }^{2}$,Dr.U.S.Singh ${ }^{3}$ \\ (Assistant Professor, MGM Medical College Jamshedpur, Jharkhand, India)
}

\begin{abstract}
Infertility is defined as inability of couple to achieve conception after one year of unprotected coitus. The purpose of investigation is to assess chance of achieving pregnancy and to identify treatable factors. In spite of many investigatory tools available, endometrial histology is a sensitive indicator of ovarian function. Aim of the study is to determine cause of infertility by morphological pattern of endometrium, to assess importance of luteal phase defect and to determine incidence of Tuberculous endometritis as an etiological factor. Study was carried out in the Pathology Dept. M.G.M.Medical college, Jamshedpur. The study included 79 endometrial biopsies wth complaint of infertility. Routine histopathological processing and staining was done with hematoxylin and eosin. Out of 73 cases of primary infertility, $21.92 \%$ were in proliferative phase, $65.75 \%$ were in secretory phase. Luteal phase defect was found in $8.22 \%$ and just $1.37 \%$ cases were reported as tuberculous endometritis. In developing countries like India, histopathological study of endometrium forms an important, safe, and cheaper diagnostic tool in cases of primary and secondary infertility where expensive, immunological and hormonal assays are not easily available or affordable.
\end{abstract}

Keywords: Endometrium, Hematoxylin Infertility, Tubercuolous endometritis,

\section{Introduction}

Infertility has become a medical as well as social problem. This can cause intense agony and trauma to the infertile couple. There is a huge stigma attached to being infertile and it has negative implications in Indian society, especially for women. It is assumed that the desire to have a child is normal and parenthood is the part of the natural order of things. In ordinary course sexually mature male and female, after a short period of conjugal life beget a child and complete the nature's cycle of reproduction. When couple fails to conceive, then they are branded as infertile. The incidence of infertility varies from region to region. Out of ten approximately one marriage is barren(1). In India around 10.2 million couples are infertile(2). Infertility affects both men and women equally. About one third of the cases are due to male factor, one third to the female and the remaining to the combination of both partner.

\section{Infertilty has been defined as:}

1.WHO(World Health Organization)- Infertility is defined as no conception after at least 12 months of unprotected intercourse.

2.Current definition: Failure to conceive following one year of unprotected intercourse if under 35 years of age or 6 months if over 35 .

Infertility may be further classified as primary infertility, in which no previous pregnancies have occurred and secondary infertility, in which a prior pregnancy, although not necessarily a live birth, has occurred(3). Sterility implies an intrinsic inability to achieve pregnancy, where as infertility implies decrease in the ability to conceive(4). Investigation for infertility should be started as early as possible, when couple arrives with complaint of infertility. The age factor is important as the day specific probability of conception declines with age. An association between the age of a women and reduced fertility has been well documented. The decline in the fecundability begins in the early $30 \mathrm{~s}$ and accelerate during the late $30 \mathrm{~s}$ and early 40 s. Therefore investigation and treatment should be undertaken as early as possible. Many investigatory tools are available to diagnose the infertility but the endometrial biopsy remains the gold standard investigation. Endometrial biopsy is a sensitive indicator as it reflects the ovarian function. It also gives information about other pathological lesions leading to infertility.

\section{A Histopathological Study of Endometrium in Infertility}

Glycogen and metabolic products are important as it serves as a source of energy for developing and maintaining an embryo(5). When endometrium fails to produce adequate amount of glycogen, it gives rise to condition in death of ovum either before or after implantation. This leads to sterility or habitual abortion. The present study has been taken to study abnormalities in endometrium in case of infertility. 


\section{Material And Methods}

The present study was carried out in the Department of Pathology, M.G.M. Medical college Jamshedpur. The present study is a prospective analysis of 79 endometrial biopsies received in the Department of pathology from Obstetrics and Gynaecology Department of M.G.M.Medical College, Jamshedpur and other adjacent clinics. The patients with complaints of infertility (primary or secondary) were included in the study. Detailed clinical history regarding menstrual cycle, Last Menstrual period, age at marriage and obstetric history in case of secondary infertility were obtained. Tissue of endometrial biopsy was fixed in both formal saline and alchoholic formaldehyde(6). After fixation tissue was grossly examined for any abonormalities. Tissue was processed, paraffin blocks were made and 5-6 micron thickness of sections were cut. The sectioned were stained with Hematoxylin and Eosin(7). The stained sections was studied for morphology of endometrium and dating of the endometrium. Special stain (Ziehl Neelson stain) were used for the detection of acid fast bacilli in case of granulomatous endometritis.

\section{Results}

The various morphological patterns of endometrium in infertility patients belonging to secretory phase, proliferative phase and simple cystic hyperplasia were documented in the present study. In a total of 79 endometrial biopsies studied, $73(92.40 \%)$ cases belonged to primary infertility and the remaining $6(7.60 \%)$ cases to secondary infertility (Table -1). In present study a total of 79 cases were studied. Out of which 72 cases were primary infertility and 6 cases were of secondary infertility. Majority of cases belonged to primary infertility. All secondary infertility cases have a previous history of conception.

Table 1: The different type of Infertility patient

\begin{tabular}{|c|c|c|}
\hline Type of infertility & Number & Percentage \\
\hline Primary & 73 & 92.4 \\
\hline Secondary & 6 & 7.6 \\
\hline Total & 79 & \\
\hline Inference & $\begin{array}{c}\text { Majority of cases are of primary } \\
\text { infertility. }\end{array}$ & \\
\hline
\end{tabular}

Data pertaining to age distribution in different infertile patients were given in Table -2 . The youngest patient seen was 21 years old and eldest was 40 years in primary infertility. The youngest patient seen was 26 years old and eldest was 38 years in secondary infertility.

Table 2: Distribution of cases according to age

\begin{tabular}{|c|c|c|c|c|}
\hline \multirow{2}{*}{$\begin{array}{c}\text { Age group } \\
\text { (years) }\end{array}$} & \multicolumn{2}{|c|}{ Primary infertility } & \multicolumn{2}{c|}{ Secondary infertility } \\
\cline { 2 - 5 } & No. & $\%$ & No. & $\%$ \\
\hline $21-25$ & 15 & 20.54 & ---- & ---- \\
\hline $26-30$ & 21 & 28.76 & 2 & 33.33 \\
\hline $31-35$ & 26 & 35.61 & 3 & 50 \\
\hline $36-40$ & 11 & 15.08 & 1 & 16.66 \\
\hline Total & 73 & 100 & 6 & 100 \\
\hline
\end{tabular}

A Histopathological Study of Endometrium in Infertility

Data pertaining to distribution of cases according to duration of infertility is given in Table 3. In Primary infertility maximum number of cases $65(89.04 \%)$ belong to $1-5$ years of duration of infertility followed by $8(10.96 \%)$ cases belong to $6-10$ years of infertility. In Secondary infertility out of 6 cases $4(66.67 \%)$ patients belong to $1-5$ years of infertility and 2 cases $(33.33 \%)$ belong to $6-10$ years of infertility.

Table 3: Distribution of cases according to duration of infertility

\begin{tabular}{|c|c|c|c|c|}
\hline \multirow{2}{*}{$\begin{array}{c}\text { Duration of } \\
\text { infertility } \\
\text { (years) }\end{array}$} & \multicolumn{2}{|c|}{ Primary infertility } & \multicolumn{2}{c|}{ Secondary infertility } \\
\cline { 2 - 5 } & No. & $\%$ & No. & $\%$ \\
\hline $1-5$ & 65 & 89.04 & 4 & 66.67 \\
\hline $6-10$ & 8 & 10.96 & 2 & 33.33 \\
\hline $11-15$ & -------- & --- & --- \\
\hline Total & 73 & 100 & 6 & 100 \\
\hline
\end{tabular}


Table 4: Histological diagnosis in primary and secondary infertility

\begin{tabular}{|c|c|c|c|c|}
\hline \multirow{2}{*}{ Histological diagnosis } & \multicolumn{2}{|c|}{ Primary infertility } & \multicolumn{2}{c|}{ Secondary infertility } \\
\cline { 2 - 5 } & No. & $\%$ & No. & \% \\
\hline Secretory endometrium & 48 & 65.75 & 2 & 33.33 \\
\hline $\begin{array}{c}\text { Proliferative } \\
\text { endometrium }\end{array}$ & 16 & 21.92 & 1 & 16.67 \\
\hline Luteal phase defect & 6 & 8.22 & -- & -- \\
\hline $\begin{array}{c}\text { Simple cystic } \\
\text { hyperplasia }\end{array}$ & 2 & 2.74 & 1 & 16.67 \\
\hline $\begin{array}{c}\text { Tuberculous } \\
\text { endometritis }\end{array}$ & 1 & 1.37 & 6 & 100 \\
\hline Total & 73 & 100 & & \\
\hline
\end{tabular}

\section{Discussion}

The present study consists of 79 cases of infertility, out of which 73 were of primary infertility and 6 cases were of secondary infertility. In the present study, incidence of primary infertility was $92.40 \%$ and secondary infertility was 7.60\%. Jhaveri et al (1972)(8) and MP Zawar (2002)(9) have reported incidence of primary infertility $80.25 \%$ and $77.7 \%$ respectively while that of secondary infertility was $19.75 \%$ and $22.5 \%$ respectively in their series of cases. The incidence of secondary infertility has been found to be less than the incidence of secondary infertility in similar study done previously. It may be due to widespread prevalence of small family norm, where couple being satisfied by a single child.

The maximum number of cases of infertility $(34.25 \%)$ was found to fall in age group of 31-35 years, which was slightly higher than previous studies. It may be due to the fact that the present study being done on patients in Medical college, which being an apex institute of the state of the Kolhan region receives most of the referral cases.

\section{A Histopathological Study of Endometrium in Infertility}

In primary infertility group $89.04 \%$ patients came in $1-5$ years of duration of infertility. In secondary infertility group $66.67 \%$ of women presented themselves for investigation of infertility after 1-5 years of secondary infertility. Now a days duration of infertility has decreased due to the introduction of in vitro fertilization and various assisted reproductive technologies. Human endometrium is the site, where nidation of young fertilized ovum takes place. Well developed follicle and efficient corpus luteum make the endometrium favourable for the successful implantation of blastocyst and continuation of pregnancy. The present study evaluated the adequacy of endometrial development based on correlating menstrual history with glandular and stromal morphology. Anovulatory cycle is the commonest cause of infertility in present series. Anovulatory cycle was seen in $22.78 \%$ cases. The present study was compared with previous studies done by other author.

Table - Comparision of percentage of ovulatory and anovulatory endometrium

\begin{tabular}{|lcc|}
\hline Author \& year & percentage of anovulatory endometrium & percentage of ovulatory \\
\hline Endometrium & & \\
\hline Shetty(1959)(10) & 15.2 & 74.8 \\
\hline Gupta et al (1980)(11) & 22.8 & 68.5 \\
\hline Sareen(1984)(12) & 19 & 79 \\
\hline Jadhav \& Raichur(1987)(13) & 25 & 75 \\
\hline Sabharwal BD(1987)(14) & 12 & 84 \\
\hline Krishnamohan et al (1993)(15) & 10 & 87.5 \\
\hline Neil Shastrabudhe(2001)(16) & 34.2 & 62.36 \\
\hline Zawar MP $(2002)(9)$ & 28.2 & 67.4 \\
\hline Present study & 22.78 & 63.30 \\
\hline
\end{tabular}

The luteal phase defect is diagnosed by using Jone's (1976) criteria. Luteal phase defect may be the cause of infertility in ovulatory cycle. Wentz AC(17), Michael Soules(18). and Arup Kumar(19) found luteal phase defect in $19 \% .16 \%$ and $5 \%$ of infertility patients respectively. In present study luteal phase defect was found in $8.86 \%$ cases. This luteal phase defect can be diagnosed by measuring serum progesterone level. The serum progesterone level is lower than $10 \mathrm{ng} / \mathrm{ml}$ one week prior to the start of menstruation or 7 days after the LH surge in luteal phase defect.

Table- Comparision of luteal phase defect in ovulatory endometrium.

\begin{tabular}{|lc|}
\hline Author \& year & luteal phase defect in percentage \\
\hline Driessen F((1980)(20) & 27 \\
\hline Gupta et al (1980) & 8.1 \\
\hline Sareen(1984) & 39 \\
\hline
\end{tabular}




\begin{tabular}{|lc|}
\hline Krishnamohan et al (1993) & 7.5 \\
\hline Neil Shastrabudhe(2001) & 15.8 \\
\hline Zawar MP (2002) & 20 \\
\hline Present study & 8.86 \\
\hline
\end{tabular}

Cystoglandular hyperplasia was seen in $2.53 \%$ of cases in present study. Gupta et al, Sabharwal, Krishnamohan and Shastrabudhe found endometrial hyperplasia in $5.9 \%, 2.66 \%, 2.5 \%$ and $4.4 \%$ respectively. This endometrial hyperplasia may be due to long standing follicular persistence, repeated anovulatory cycle and high level of unopposed estrogen. Tuberculous endometritis formed a minor cause of infertility in the present study. It was found in $2.53 \%$ cases of infertility. The incidence of tuberculous endometritis has been found to be reduced when compared with the similar previous study. This may be due to the widespread availability of treatment for tuberculosis.

Table- Comparision of percentage of tuberculous endometritis

\begin{tabular}{|lc|}
\hline Author \& year & Comparision of percentage of tuberculous endometritis \\
\hline Gupta et al $(1980)$ & 1.5 \\
\hline Sareen(1984) & 2 \\
\hline Shastrabudhe(2001) & 2.6 \\
\hline Zawar MP (2002) & 2.6 \\
\hline Present study & 2.53 \\
\hline
\end{tabular}

In the present study PAS stain was done in 75 cases of infertility. This stain helps in the assessment of glycogen content. This glycogen plays an important role for the proper implantation and subsequent growth of fertilized ovum in the uterus. Glycogen should be present in the glandular secretion in adequate amount. High content of glycogen serve as a major source of energy for maintaining an embryo. Sharma S(21), Gupta PL(22) and Zawar MP found glycogen deficiency in $28.5 \%, 52 \%$ and $30 \%$ of infertility patients respectively. A Histopathological Study of Endometrium in Infertility

\section{Conclusion}

The present study was done on 79 women presenting with the complaint of infertility ( primary and secondary infertility). Endometrial biopsies were taken in all cases and gland \& stroma were studied histologically. Maximum number of patients $(87.34 \%)$ presented themselves for the investigation of infertility after 1-5 years of marriage. Common age group for infertile women was 31-35 years. Maximum number of cases $(22.78 \%)$ of infertility were found to be due to anovulatory cycle. Glycogen deficiency was seen mainly in the luteal phase defect indicating histopathologic immaturity of endometrium. This immature endometrium prevents implantation of the fertilized ovum and subsequent development of fetus. Histopathological study of endometrium forms an important, safe and cheaper diagnostic tool in cases of primary and secondary infertility.

Sophia J Kleefman SA. Infertility in women. $1^{\text {st }}$ Ed. Philadelphia.

[2]. Dawn CS. Textbook of Gynaecology. $5^{\text {th }}$ Ed

[3]. Berek \& Novak's Gynaecology 14 ${ }^{\text {th }}$ Ed. 30: 1186.

[4]. Alan H. DeCherney, Lauren Nathan. Current Obstetrics \& Gynaecologic Diagnosis and treatment, 53:979.

[5]. Maeyama M, Sudo I, MatsuoI, Wakaharak. Endometrial glycogen- an important parameter of infertility. Fertil Steril 1977;28:15963.

[6]. John D. Bancroft, Marilyn Gamble Theory and practice of Histological Techniques $5^{\text {th }}$ Ed. 5:75.

[7]. John D. Bancroft, Marilyn Gamble. Theory and Practical of Histological Techniques, $5^{\text {th }}$ Ed. 8:125-130.

[8]. Jhaveri CL, Shah RM, Bhatt HK. Endometrial glycogen - important in infertility. Proc All India Obstet Gynaecol Cong 1972:25560.

[9]. Zawar MP. Histopathological study of endometrium in infertility. Indian J Pathol Microbiol 2003;46(4):630-633.

[10]. Shetty BMC. Endometrium in infertility. J Obstet Gynaecol India 1959;10:139-41.

[11]. Gupta AN, Agrawal S Vashishtak. Study endometrium in infertile women. J Obstet Gynaecol India 1980;8:27-32.

[12]. Sareen Pm, Kalra R, Lodha SK, Kalra VB. Significance of endometrial glycogen in primary sterility. Indian J Obstet Gynaecol 1984;34:877-81.

[13]. Jadhav MV, Raichur BS.Endometrium in infertility.Indian J Pathol Microbiol 1987;30:307-11.

[14]. Sabharwal BD, Sofat R,Cvhander K, Kumar R. Endometrial pattern \& its glycogen content in case of sterility. Indian J Obstet Gynaecol 1987;37:718-21.

[15]. Krishnamohan VE, Nair B, Shenoy S. Histopathological study of endometrium in primary sterility. Indian J Obstet Gynaecol 1993;43:580-4.

[16]. Shastrabudhe NS, Shinde S, Jadhav MV. Endometrium in infertility. . Indian J Obstet Gynaecol 2001;51:100-2.

[17]. Wentz AC, Kosay L, Parker RA.The impact of luteal phase inadequacy in an infertile population. Am J Obstet Gynaecol 1990;162:937-40.

[18]. Soules M. Luteal phase deficiency: the infertile women. Obstet Gynaecol , Clin North Am 1987;14:865-85.

[19]. A Histopathological Study of Endometrium in Infertility

[20]. Majhi AK. Luteal phase defect : still a mystery in female infertility. Obstet Gynaecol Today 2002;4:217-22. 
[21]. Drissen FP, Holwedra J, Kremmer PJ. The significance of dating on endometrial biopsy for the prognosis of the infertile couple. Int J Fertil 1980;25:112-6.

[22]. Sharma SC, Banerjee AK, Hasan MI, Endometrial glycogen in sterility. J Obstet Gynaecol India 1984;34:1073-76.

[23]. Gupta PL, Jethani M. Endometrial glycogen - an important parameter of infertility J Obstet Gynaecol India 1994;44:804-7. 